\title{
Prospek Bank Syariah Pasca Undang-Undang Nomor 10 Tahun 1998 Tentang Perubahan Undang-Undang Nomor 7 Tahun 1992 Tentang Perbankan
}

Oleh: Ismail

\begin{abstract}
ABSTRAK
Sejak diundangkannya undang-undang Nomor 10 Tahun 1998 tersebut, maka pemerintah dalam hal ini bank Indonesia menggunakan dual sistem perbankan, yaitu perbankan dengan sistem bunga yang di anut oleh perbankan konvensional dan perbankan dengan sistem bagi hasil.dengan demikian perbankan konvensional dapat membuka layanan perbankan dengan sistem bagi hasil.

Kinerja ini semakin nyata ketika badai krisis ekonomi melanda indonesia. Ketika perbankan konvensional banyak yeng terpuruk, perbankan syariah relatif dapat bertahan bahkan menunjukkan perkembangan. Data menunjukkan bahwa pada akhir 1996, jumlah keseluruhan kantor, baik kantor pusat, kantor cabang, kantor capem, maupun kantor kas, yaitu 41 kantor. Bulan januari 2003, jumlahnya telah menjadi 116 kantor.

Ini membuktikan bahwa secara konseptual, perbankan syariah memang sesuai dengan tuntunan perkembangan zaman serta sudah menjadi kewajiban sejarahnya untuk lahir dan berkembang menjadi sistem perbankan alternatif yang sesuai dengan fitrah hidup manusia. Walapun demikian, kesempurnaan konsep yang berdasarkan konsep ilahiah ini tetap terus harus disesuaikan dengan tuntutan zaman agar tetap dapat diterapkan dalam kehidupan bisnis yang nyata. Berangkat dari pemikiran itulah diperlukan alternatif-alternatif pemikiran yang dapat menyempurnakan konsep pengembangan perbankan syariah dimasa depan.

Tantangan pertama yang berada di depan mata adalah mampukah perbankan syariah memerankan fungsi intermediasi secara baik sehingga segera dapat menggerakkan sektor ril. Tantangan kedua adalah mampukah perbankan syariah berkembang di habitatnya yang subur'(negeri dengan penduduk muslim terbesar di dunia) serta menjadi contoh sukses bagi negara-negara lain dalam mengembangkan perbankan syariah. Tantangan ketiga, dimasa depan perbankan syariah harus mampu menjadi rahmatan lil alamin.
\end{abstract}




\section{PENDAHULUAN}

Sudah merupakan pendapat umum bahwa tidak mungkin ada sistem perbankan islam karena persoalan bunga yang merupakan persoalan utama dalam pengoperasian bank konvensional, yang tidak di benarkan dalam ajaran islam. Bunga yang diterapkan dalam perbankan konvensional dapat mendorong peningkatan saldo tabungan dan juga mendorong minat masyarakat untuk menyimpan dana dan melakukan transaksi dengan pihak bank. Tanpa bunga ini, dunia perbankan tidak mungkin berkembang. Lain halnya dengan sistem keuangan islam yang menganut perbankan dengan sistem tanpa bunga tidak memberikan tempat untuk mendirikan lembaga keuangan yang menggunakan sistem bunga. ${ }^{1}$

Konsep perbankan islam( selanjutnya disebut perbankan syariah) adalah relatif masih tergolong baru bagi masyarakat indonesia, termasuk bagi masyarakat muslim itu sendiri. Walaupun pemikiran konsep dasar perbankan syariah itu sudah berjalan lama, dalam kenyataannya di indonesia praktek bank syariah yang bebas riba itu, namun baru pada tahun 1992 indonesia memiliki sebuah bank islam, yaitu bank muamalat di jakarta.

Tidak ada sistem ekonomi yang dapat mepertahankan katahanan dan memberikan sumbangan secara positif terhadap pencapaian tujuan-tujuan sosio-ekonomi, melainkan tanpa didukung oleh pengaturan keuangan dan sistem perbankan yang handul dan mampu bersaing ditengah percaturan bisnis perbankan. Ketidakstabilan ekonomi dewasa ini diakibatkan oleh adanya ekspansi yang berlebihan terhadap perbankan dan juga adanya kontraksi kredit dalam sistem perbankan yang berbasis bunga, sehingga mengakibatkan ketidak merataan pendapatan. Dan tidak mungkin menghapuskan sumber-sumber ketidakstabilan yang melilit dunia perbankan, tanpa mengaktifkan kebijakan fiskal dan moneter juga merekonstruksi perekonomian. $^{2}$

Uang dan sistem perbankan mempunyai peranan penting dalam perekonomian islam sama halnya dengan sistem perekonomian lain. Meskipun demikian, untuk memainkan peranan yang berdasarkan prinsip islam, hal ini perlu diperbaharui dan dikelola dengan cara yang islami sehingga serasi dengan etos kerja dan mampu memenuhi aspirasi umat.

Dalam perbankan konvensional praktek operasionalnya dilaksanakan dengan menggunakan sistem bunga (riba), dan hal ini dilarang dalam ajaran islam. Persoalan ini menimbulakan kebutuhan akan perlunya didirikan lembaga-lembaga keuangan yang kegiatan usahanya berdasarkan bukan pada sistem bunga. Hal ini untuk menjamin maqashid asy-

\footnotetext{
${ }^{1}$ Muhammad Muslehuddin, sistem perbankan dalam islam(cet II, jakarta: Rineka Cipta,1994),h.50

${ }^{2}$ M. Umer Chapra,Alquran menuju sistem moneter yang adil,(cet,I,yogyakarta: dana bhakti prima yasa, 1997),h.1
} 
syariah bagi umat manusia dalam persoalan perbankan. Perbankan syariah adalah merupakan jawaban dan sebagai alternatif. Praktek-praktek perbankan syariah harus dilaksanakan dengan menggunakan instrumen-instrumen keuangan yang bertumpu pada asas pembagian keuangan dan kerugian, bukan pada bunga. ${ }^{3}$

Ketentuan tentang kegiatan usaha bank berdasarkan primsip syari’ah dalam UU NO. 7 tahun 1992, dinilai sangat terbatas, yakni hanya menyangkut kegiatan pembiayaan dan tidak mengatur penghimpun dana. Maka diatur kembali dalam undang-undang yang baru secara lebih jelas, lengkap dan lebih eksplisit, baik yang mengatur tentang penghimpunan dana maupun penyediaan pembiayaan.

Undang-undang baru yang dimaksud adalah undang-undang nomor 10 tahun 1998 tentang perubahan undang-undang nomor 7 tahun 1992 tentang perbankan. Dalam undangundang tersebut terdapat penjelasan yang memberikan peluang yang lebih besar bagi pengembangan perbankan syariah di seluruh indonesia. ${ }^{4}$

\section{Perbankan Syariah Dalam Tata Hukum perbankan Indonesia}

A. kondisi Perbankan Syariah di Indonesia

Sejarah berdirinya perbankan dengan sistem bagi hasil, didasarkan pada dua alasan utama, yaitu; (1) karena adanya pandangan bahwa bunga (interest) pada bank konvensional hukumnya haram karena termasuk dalam kategori riba yang dilarang dalam agama, bukan saja pada agama islam tetapi juga oleh agama samawi lainnya, (2) dari aspek ekonomi, penyerahan resiko usaha terhadap salah satu pihak dinilai melanggar norma keadilan. Dalam jangka panjang sistem perbankan konvensional akan menyebabkan penumpukkan kekayaan pada segilintir orang yang memiliki kapital besar. ${ }^{5}$

Dilihat dari aspek ini, peluang pengembangan bank syariah di indonesia cukup besar, karena indonesia merupakan negara yang memiliki penduduk muslim paling besar. Dari aspek hukum, yang mendasari perkembangan bank syariah di indonesia adalah UU no.7 tahun 1992. Dalam UU tersebut prinsip syariah masih samar, yang dinyatakan sebagai prinsip bagi hasil. Prinsip perbankan syariah secara tegas baru dinyatakan dalam UU no.10 tahun 1998.

Walaupun pengembangan bank syariah secara intensif masih relatif baru, pengembangannya tidak berlandaskan infant industries argument yang berdasarkan proteksi

\footnotetext{
${ }^{3}$ Sutan Remy Sjahdeini, perbankan islam dan kedudukan dalam tata hukum perbankan indonesia (cet. I; jakarta: Pustaka utama Grafiti,1999),h. 19

${ }^{4}$ Zainul Arifin, memahami Bank syariah : lingkup peluang, tantangan dan prospek, (cet. I; jakarta: Alvabet,1999),h.115

5 Jhon M Keynes, The General Theory Of Employment, Interest and Money (New York, Harcourt Brace, 1936), h.74
} 
dan keistimewaan-keistimewaan. ${ }^{6}$ Pembedaan pengaturan lebih disebabkan karena memang perbankan syariah beroperasi dengan sistem yang berbeda dengan perbankan konvensional.

B. Ruang Lingkup Perbankan syariah dalam Tata Hukum Indonesia

Dalam UU no.7 tahun 1992 tidak dikenal istilah prinsip syariah. Istilah yang dikenal sebelumnya adalah prinsip bagi hasil, walaupun yang dimaksud sebenarnya adalah prinsip syariah. Berdasarkan pada pasal 6 dan pasal 13 UU no.7 tahun 1992, dibuka kemungkinan bank untuk melakukan usaha dalam bentuk memberikan pembiayaan bagi nasabah berdasarkan prinsip bagi hasil sesuai dengan ketentuan dalam peraturan pemerintahan N0.72 tahun 1992 tentang bank berdasarkan prinsip bagi hasil.

Ketentuan tentang kegiatan usaha bank berdasarkan prinsip syariah dalam UU no.7 tahun 1992 sangat terbatas, yakni hanya menyangkut kegiatan pembiayaan dan tidak diatur tentang penghimpunan dana. Maka diatur kembali dalam Undang-undang yang baru secara lebih jelas dan lengkap dan lebih eksplisit, baik yang menyangkut penghimpunan dana maupun penyediaan pembiayaan.

Dengan dimasukannya prinsip syariah pada sistem perbankan maka diharapkan akan benar-benar mengakomodasi operasional bank syariah. Sejalan dengan itu juga diharapkan adanya pengembangan, pembinaan dan sosialisasi dari bank indonesia akan lebih maksimal. Tentunya dampak berikutnya juga kita harapkan pada pengembangan lembaga keuangan BMT.

C. Jenis Kegiatan usaha Bank syariah Menurut Undang-undang Perbankan

Undang-undang perbankan, baik UU no 7 tahun 1992 sebelum diubah dengan UU no.10 tahun 1998, menganut asas-asas pembatasan jenis kegiatan usaha perbankan sebagai perwujudan dari prinsip kehati-hatian yang harus dianut oleh dunia perbankan indonesia. Bank-bank umum hanya boleh melakukan kegiatan usaha yang jelas disebutkan dalam pasal 6 dan 7 UU no.7 tahun 1992, sebagaimana kemudian diubah dalam UU.no 10 tahun 1998, dimana pasal 6 Undang-undang ini menyatakan :

a. Menghimpun dana dari masyarakat dalam bentuk simpanan berupa Giro, deposito berjangka, sertifikat deposito, tabungan dan atau yang lainnya yang dipersamakan dengan itu;

b. Memberikan kredit;

c. Menerbitkan surat pengakuan utang;

${ }^{6}$ Zainul Arifin, Memahami Bank Syariah lingkup peluang tantangan dan proyek (cet 1, jakarta Alvabet,1999),H.135 
d. membeli, menjual atau menjamin atas resiko sendiri ataupun untuk kepentingan dan atas perintah nasabahnya;

e. memindahkan uang, baik untuk kepentingan sendiri maupun kepentingan nasabah;

f. Menempatkan dana pada, meminjam dana dari, atau meminjamkan dana pada bank lain baik dengan menggunakan surat, sarana telekomunikasi, maupun dengan wesel untuk cek, atau sarana lainnya;

g. Menerima pembayaran dari tagihan atas surat berharga dan melakukan perhitungan dengan atau antar pihak ketiga;

h. Menyediakan tempat untuk menyimpan barang dan surat berharga;

i. Melakukan kegiatan penitipan untuk kepentingan pihak lain sesuai kontrak;

j. Melakukan penempatan dana dari nasabah ke nasabah yang lain dalam bentuk surat berharga yang tidak tercatat di bursa efek;

k. “dihapus" berdasarkan UU No.10 tahun 1998;

1. Melakukan kegiatan anjak piutang, usaha kartu kredit, dan kegiatan wali amanat;

m. Melakukan pembiayaan dan atau melakukan kegiatan lain berdasarkan prinsip syariah sesuai ketentuan yang ditetapkan oleh bank indonesia;

n. Melakukan kegiatan lain yang lazim dilakukan oleh bank sepanjang tidak bertentangan dengan undang-undang ini dan peraturan perundangan yang berlaku. ${ }^{7}$

Sedangkan pasal 7 berbunyi sebagai berikut;

Selain melakukan kegiatan usaha sebagaimana dimaksud pada pasal 6, bank umum dapat pula:

a. Melakukan kegiatan dalam valuta asing dengan memenuhi ketentuan yang diterapkan oleh bank indonesia;

b. Melakukan kegiatan penyertaan modal pada bank atau perusahaan lain dibidang keuangan, seperti sewa guna usaha, modal ventura, perusahan efek, asuransi, serta lembaga kliring penyelesaian dan penyimpanan dengan memenuhi ketentuan yang ditetapkan oleh bank indonesia; dan

c. Melakukan kegiatan penyertaan modal sementara untuk mengatasi akibat kegagalan kredit atau kegagalan pembiayaan berdasarkan prinsip syariah dengan syarat harus menarik kembali penyertaan dengan memenuhi ketentuan yang ditetapkan oleh bank indonesia; dan

7 Sutan Remy Sjahdeini, perbankan islam dan kedudukannya dalam tata hukum perbankan indonesia,(jakarta: pustaka utama grafiti,1999), h.253 
d. Bertindak sebagai pendiri dana pensiun dan pengurus dana pensiun sesuai dengan ketentuan peraturan perundangan dana pensiun yang ada.

Daftar kegiatan usaha seperti disebutkan diatas, merupakan suatu positive list, yaitu daftar dari kegiatan yang boleh dilakukan dan kegiatan yang tidak disebutkan dalam daftar tersebut merupakan kegiatan yang tidak boleh dilakukan oleh suatu bank. Jenis kegiatan usaha diatas tidak boleh ditambah-tambah. Sesuai dengan pasal 10 UU No.7 tahun1992, yang berbunyi sebagai berikut:

Bank umum dilarang

a. Melakukan penyertaan modal, kecuali sebagaimana dimaksud pada pasal 7 huruf b dan huruf c;

b. Melakukan usaha pengasuransian;

c. Melakukan usaha lain diluar kegiatan usaha sebagaimana dimaksud dalam pasal 6 dan pasal 7

Kegiatan-kegiatan umum yang boleh umum yang boleh dilakukan oleh bank umum syariah (BUS) mendapat penegasan dan rincian dalam surat keputusan direksi Bank Indonesia No. 32/34/kep/Dir, tentang bank umum berdasarkan prinsip syariah, tanggal 12 mei 1999.

Kegiatan-kegiatan usaha yang boleh dilakukan oleh bank perkrekditan rakyat didaftar oleh undang-undang perbankan dalam pasal 13 UU No.7 tahun 1992, yang berbunyi sebagai berikut:

Usaha bank perkreditan rakyat meliputi

a. Menghimpun dana dari masyarakat dalam bentuk simpanan berupa deposito berjangka, tabungan atau bentuk lainnya yang dipersamakan dengan itu;

b. Memberikan kredit;

c. Menyediakan pembiayaan dan penempatan dana berdasarkan prinsip syariah sesuai dengan ketentuan yang diterapkan oleh bank indonesia;

d. Membentuk dananya dalam bentuk sertifikat bank indonesia (SBI), deposito berjangka, sertifikat deposito dan atau tabungan pada bank lain.

Menurut pasal 14 UU No.7 tahun 1992, bank perkreditan rakyat hanya boleh melakukan kegiatan-kegiatan usaha yang tercantum dalam pasal 13 tersebut yaitu sebagaimana ditentukan oleh pasal 14 undang-undang tersebut yang berbunyi:

Bank perkreditan rakyat dilarang:

a. Menerima simpanan berupa giro dan ikut serta dalam lalu lintas pembayaran;

b. Melakukan kegiatan usaha dalam valuta asing; 
c. Melakukan penyertaan modal;

d. Melakukan usaha pengasuransian;

e. Melakukan usaha lain diluar kegiatan usaha sebagaimana dimaksud dalam pasal $13 .^{8}$

Kegiatan usaha yang boleh dilakukan oleh bank perkreditan rakyat syariah (BPRS) mendapat penegasan dan rincian dalam surat keputusan direksi bank indonesia No. 32/36/kep/Dir tentang bank perkreditan rakyat berdasarkan prinsip syariah.

Dari ketentuan pasal 10 ayat 1 UU No.7 tahun 1992, dapat diketahui bahwa bank umum tidak boleh melakukan penyertaan modal kecuali apabila penyertaan modal itu dilakukan:

1. Pada perusahaan bank atau perusahaan dibidang keuangan (pasal 7 huruf b); atau,

2. Dalam rangka mengatasi akibat kegagalan kredit, dengan syarat harus menarik kembali pernyataannya, dengan memenhi yang di tetapkan oleh bank indonesia (pasal 7 huruf c).

Mengingat pada pasal 6 huruf $\mathrm{m}$, bank umum boleh menyediakan pembiayaan dan atau melakukan kegiatan lain berdasarkan prinsip syariah, sedangkan menurut pasal 13 huruf c, bank perkreditan rakyat boleh menyediakan pembiayaan dan penempatan dana berdasarkan prinsip syariah seperti halnya bank umum. Sehubungan dengan berlakunya pasal 10 ayat 1 dan pasal 14 huruf c, timbul pertanyaan apakah ketentuan pasal 10 ayati tersebut berlaku pula bagi bank umum yang melakukan kegiatan berdasarkan prinsip syariah? Pertanyaan yang sama dapat diajukan pada bank perkreditan rakyat sesuai dengan berlakunya pasal 14 huruf $\mathrm{c}$.

Pertanyaan tersbut layak diajukan mengingat salah satu kegiatan perbankan islam melakukan penyertaan modal, yaitu dalam bentuk transaksi musyarakah. Kalau penyertaan modal sebagai kegiatan bank syariah dilarang, maka kegiatan musyarakah di indonesia dilakukan melalui pendirian lembaga pembiayaan yang nota bene bukan merupakan lembaga bank yang tunduk pada undang-undang perbankan.

\footnotetext{
${ }^{8}$ Ibid,h. 229
} 
Kejelasan diberikan oleh pasal 1 ayat 13 mengenai apa yang dimaksudkan dengan prinsip syariah. Menurut pasal 1 ayat 13 prinsip syariah adalah;

Pasal 1

Ayat 13

Prinsip syariah adalah aturan perjanjian berdasarkan hukum islam antara bank dan pihak lain untuk penyimpanan dana atau pembiayaan kegiatan usaha, atau kegiatan lainnya yang dinyatakan sesuai syariah, antara lain pembiayaan berdasarkan prinsip bagi hasil (mudharabah), atau pembiayaan berdasarkan penyertaan modal (musyarakah), atau pembiayaan barang modal berdasarkan prisnisp sewa murni tanpa pilihan (ijarah) atau dengan adanya pilihan pemindahan kepemilikan atas barang yang disewa dari pihak bank oleh pihak lain (ijarah wa iqtina). ${ }^{9}$

Dari pengertian prinsip syariah diatas, maka secara yuridis ketentuan larangan sebagaimana yang dimaksud dalam pasal 10 huruf a dan pasal 14 huruf c hanya berlaku bagi bank yang semata-mata melakukan kegiatan usaha bank konvensional. Namun bagi bank syariah atau bank umum yang memiliki islamic windows boleh melakukan penyertaan modal sepanjang hal tersebut dilakukan dalam bentuk musyarakah sesuai dengan ketentuan syariah yang menganut profit and loss sharing principle.

\section{III.Prospek dan Tantangan Bank Syariah di Indonesia}

Dalam dunia perbankan di indonesia saat ini, perbankan syariah sudah tidak lagi dianggap sebagai tamu asing. Hal ini disebabkan oleh kinerja dan kontribusi perbankan syariah terhadap perkembangan industri perbankan di indonesia selama 10 tahun terakhir.

Kinerja ini semakin nyata ketika badai krisis ekonomi melanda indonesia. Ketika perbankan konvensional banyak terpuruk, perbankan syariah relatif dapat bertahan bahkan menunjukkan perkembangan. Data menunjukkan bahwa pada akhir 1996, jumlah keseluruhan kantor, baik kantor pusat, kantor cabang, kantor capem, maupun kantor kas, yaitu 41 kantor. Bulan januari 2003 jumlahnya telah menjadi $116 .^{10}$

Strategi utama dalam konsep pengembangan perbankan syariah di masa depan adalah transformasi. Transformasi ini terutama harus dilakukan oleh kalangan internal perbankan syariah.

\footnotetext{
${ }^{9}$ Ibid,h. 250

${ }^{10}$ Warkum Sumitro, Bank syariah di indonesia, (cet.1, jakarta: raja grafindo persada,1998),h.129
} 
Adapun proses transformasi yang diperlukan adalah :

Transformasi 1 : Dari produk syariah ke corporate syariah di masa depan, perbankan syariah tidak cukup hanya mendasar pada produk-produk syariahnya. Masyarakat tidak hanya menilai produknya, tetapi juga sistem manajemen, profil personalia, serta service delivery-nya. Dengan kata lain, perbankan syariah juga harus berarti semua aspek operasional yang dijalankan benar-benar berlandaskan pada prinsip syariah.

Transformasi 2 : Dari sentimen emosional ke rasional profesional. Salah satu kelemahan perbankan syariah adalah masih banyaknya kalangan perbankan syariah yang membidik sasarannya pada para loyalis syariah atau yang fanatik pada syariah. ${ }^{11}$

Persaingan akan bergeser kepada perbankan mana yang dapat memberikan value dan pelayanan lebih baik. Oleh karena itu, perbankan di masa depan sudah harus mengemas komunikasi yang lebih menekankan pada aspek-aspek rasional dalam proses pengambilan keputusan pelanggan. Isu halal-haram atau isu riba harus menjadi isu sekunder, sedangkan isu primernya adalah profesionalisme dari perbankan serta pelayanan yang akan diterima oleh nasabah.

Transformasi 3 : Dari nasabah muslim ke nasabah umum. Perbankan syariah juga harus membuka diri dan secara proaktif menjemput bola nasabah umum dan non-muslim. Image bahwa perbankan syariah hanya untuk kaum muslim harus segera di ubah. Dengan demikian, maka komunikasi yang dijalankan tidak lagi mengikat isu riba, tetapi isu-isu profesionalisme.

Berkaitan dengan transformasi 2 dan 3, harus ada upaya yang sungguh-sungguh untuk merubah image perbankan syariah. Jika selama ini semboyan-semboyan yang diusung lebih bersifat islami misalnya dengan istilah-istilah berkah, halal,syariah, dan sebagainya, maka kedepannya istilah-istilah tersebut dilengkapi dan diperkaya (bukan diganti) dengan istilahistilah yang lebih umum dan populer seperti melayani, terpercaya, aman, menguntungkan, bermanfaat, profesional, dan sebagainya. ${ }^{12}$

Tranformasi 4 : Dari pengusaha besar kepada orientasi yang lebih adil. Konsep perbankan syariah dimasa depan harus mampu menciptakan distribusi yang adil antara pengusaha besar dan kecil, adanya pemerataan perekonomian, serta antarpusat dan daerah. Untuk mendukung konsep ini, perbankan syariah harus melakukan pembukaan kantor cabangnya hingga level kota/kabupaten.

\footnotetext{
${ }^{11}$ Ibid, h.345

12 Jiwa Pramono, kontekstualisasi sistem ekonomi islam di indonesia (jakarta: Gramedia,1997),h.12
} 
Tranformasi 5 : Dari motif investasi ke akumulasi modal. Dalam pandangan hukum islam, investasi yang bernilai adalah pada sektor usaha karena akan membuka lapangan kerja, mengelola sumber daya, serta meningkatkan pendapatan. Oleh karena itu, dimasa depan perbankan syariah harus mempelopori pemberian "kredit murah" sehingga memotivasi masyarakat untuk berinvestasi pada sektor-sektor usaha. ${ }^{13}$

Adapun saluran-saluran komunikasi dan sosiolisasi yang dapat dipergunakan adalah : advertising dari bank syariah, generic advertisng dari asosiasi perbankan syariah, pendidikan formal dan nonformal, ulama dan tokoh masyarakat, serta publikasi melalui buku dan media massa.

\section{Konsep pengembangan bank syariah}

Perbankan sebagai lembaga intermediasi, antara surplus spending unit dengan deficit spending unit, memiliki posisi strategis dalam perekonomian nasional. Dengan demikian, upaya pengembangan perbankan nasional termasuk perbankan syariah perlu dilakukan secara berkesimbangan untuk meningkatkan kontribusinya terhadap pembangunan ekonomi. Pengembangan perbankan syariah di indonesia tidak hanya konsekuensi dari UU No.10 tahun 1998 dan UU No.23 tahun 1999, tetapi juag merupakan bagian tak terpisahkan dari upaya penyehatan sistem perbankan yang bertujuan meningkatkan daya tahan perekonomian nasional. $^{14}$

Sejarah perkembangan perbankan syariah di indonesia secara formal dimulai dengan lokakarya MUI mengenai perbankan pada tahun 1990 tentang perbankan yang mengakomodasi kegiatan bank dengan prinsip bagi hasil. Namun harus diakui bahwa sebelum tahun 1992 telah terdapat beberapa usaha pembiayaan yang menggunakan pola bagi hasil sebagai suatu eksperimentasi, pendiri bank muamalat indonesia (BMI) yang menggunakan pola bagi hasil pada tahun 1991 menandakan dimulainya era sistem perbankan ganda (dual banking system) di indonesia. Selama periode 1991-1998 hanya terdapat satu bank umum syariah dan beberapa bank perkreditan rakyat syariah (BPRS) sebagai pelaku industri perbankan syariah. ${ }^{15}$

Krisis keuangan yang melanda indonesia sejak akhir 1997 menunjukkan bahwa sistem pembiayaan berdasarkan prinsip-prinsip syariah mampu bertahan dan memiliki kinerja yang relatif lebih baik. Hal ini minimal terlihat pada angka NPFS yang lebih rendah di banding

\footnotetext{
${ }^{13}$ Ibid,h.132

${ }^{14}$ Hendratmo Purwonegoro, nasionalisasi perbankan syariah (jakarta : Ichtiar Prees,2002),h.79

15 Warkum sumitro, asas-asas perbankan islam dan lembaga-lembaga terkait (jakarta: raja grafindo perkasa, 1996),h.32
} 
sistem konvensional, tidak adanya negative spread, dan konsistensinya dalam menjalankan fungsi intermediasi. ${ }^{16}$

Dalam pengembangan perbankan syariah terdapat enam permasalahan utama yang perlu segera diatasi, yaitu:

1. kerangka pengaturan perbankan syariah yang belum lengkap.

2. jaringan kantor yang terbatas.

3. kurangnya pengetahuan dan pemahaman mengenai produk dan jasa perbankan syariah.

4. institusi pendukung yang belum lengkap dan efektif.

5. perlunya perbaikan kinerja bank syariah yang berkesinambungan.

6. kemampuan untuk memenuhi standar keuangan syariah internasional. ${ }^{17}$

Dalam pengembangan industri perbankan syariah, proses penyusun kebijakkan oleh otoritas perbankan perlu dipayungi oleh sekumpulan paradigma kebijakkan. Hal tersebut diperlukan untuk menjamin konsistensi peran dan tugas otoritas perbankan dalam pengembangan perbankan syariah. Paradigma kebijakkan yang diperlukan dalam pengembangan perbankan syariah adalah market driven, fair teatment, gradual and sustainable approach, serta secara konsisten comply to sharia principles dan international best practices. ${ }^{18}$

Dalam penetapan kebijakan-kebijakan strategis, perlu disadari bahwa kegiatan pengembangan perbankan syariah tidak dapat dilaksanakan sekaligus dalam satu tahapan. Dengan demikian, perlu ditetapkan fokus strategi jangka pendek, jangka menengah, dan jangka panjang guna mencapai sasaran yang sesuai dengan rentang waktunya.

\section{Penutup}

\section{A. Kesimpulan}

Dari uraian yang telah penulis kemukakan di atas, maka penulis mengambil beberapa konklusi pemikiran sebagai berikut.:

1. kelahiran bank syariah di indonesia didorong oleh keinginan masyarakat indonesia (terutama masyarakat islam) yang berpandangan bunga merupakan hal yang haram. Walaupaun demikian, sebenarnya prinsip bagi hasil dalam lembaga keuangan telah dikenal luas baik di negara islam maupun non-islam. Jadi bank syariah tidak berkaitan dengan kegiatan ritual keagamaan (islam) tapi lebih merupakan konsep bagi hasil usaha antara pemilik modal dengan pihak pengelola modal. Dengan demikian

\footnotetext{
${ }^{16}$ Ibid,h.57

${ }^{17}$ Hendratmo, opcit, h. 261

${ }^{18}$ R.Sudirman, opcit,h.109
} 
pengelolaan bank dengan prinsip syariah dapat diakses dan dikelola oleh seluruh masyarakat yang berminat tidak terbatas pada masyarakat islam. Walaupun tidak dipungkiri sampai saat ini bank syariah di indonesia baru berkembang pada kalangan masyarakat islam, oleh sebab itu harus ada kerjasama antara pemerintah, tokoh masyarakat, tokoh agama dan umat islam itu sendiri untuk mengembangkan perbankan syariah.

2. Dilihat dari aspek ini, peluang pengembangan bank syariah di indonesia cukup besar, karena indonesia merupakan negara yang memiliki penduduk muslim paling besar, dan masih banyaknya UKM-UKM yang menjadi mata pencarian bagi masyarakat yang berekonomi menengah ke bawah yang masih memerlukan permodalan dan pembinaan di dalam menjalankan usahanya.

3. Dari aspek hukum, yang mendasari perkembangan bank syariah di indonesia adalah undang-undang nomor 7 tahun 1992 yang selanjutnya diamandemen menjadi undangundang nomor 10 tahun 1998, yang seharusnya sudah diberlakukan keseluruh wilayah indonesia tanpa melihat presentase penduduk muslim di suatu daerah tertentu, karena untuk mencari pangsa pasar perbankan syariah tidak harus dari nasabah islam tetapi perlu mencari nasabah dari nasabah non-muslim, sehingga roda perekonomian di suatu daerah akan berjalan.

\section{B. Saran-saran}

1. Dalam pengembangan industri industri perbankan syariah, proses penyusun kebijakan oleh otoritas perbankan perlu di payungi oleh sekumpulan paradigma kebijakan, dalam hal ini masih kurangnya perangkat hukum dalam menjalankan operasionalnya.

2. Profesional bank syariah dalam layanan kepada masyarakat, jenis produk dan jasa yang ditawarkan dan fasilitas penunjang perlu di tingkatkan.

3. Perbankan syariah harusnya menjadi lembaga keuangan yang profesional dan dapat dipercaya sehingga menjadi tempat bagi proses akumulasi kapital masyarakat, dan menjadi fasilitator dalam pengembangan ekonomi umat dan masyarakat indonesia melalui perannya sebagai sumber permodalan yang mudah dan murah dan menjadi mitra sejati bagi para pelaku ekonomi lainnya. 


\section{DAFTAR PUSTAKA}

Muslehuddin Muhammad, sistem perbankan dalam islam cet II, jakarta: Rineka Cipta,1994.

Chapra M. Umer,Alquran menuju sistem moneter yang adil, cet,I,yogyakarta: dana bhakti prima yasa,1997.

Sjahdeini Sutan Remy, perbankan islam dan kedudukan dalam tata hukum perbankan indonesia ,cet. I; jakarta: Pustaka utama Grafiti,1999.

Arifin Zainul, memahami Bank syariah : lingkup peluang, tantangan dan prospek, cet. I; jakarta: Alvabet,1999.

Keyne Jhon M s, The General Theory Of Employment, Interest and Money „New York, Harcourt Brace, 1936.

Sumitro Warkum, Bank syariah di indonesia, cet.1, jakarta: raja grafindo persada,1998.

Pramono Jiwa, kontekstualisasi sistem ekonomi islam di indonesia jakarta: Gramedia,1997.

Purwonegoro Hendratmo, nasionalisasi perbankan syariah, jakarta : Ichtiar Prees,2002. 